\title{
New photoreactive tRNA derivatives for probing the peptidyl transferase center of the ribosome
}

\author{
ANTON V. MANUILOV, ${ }^{1,2}$ STEPHEN S. HIXSON, ${ }^{3}$ and ROBERT A. ZIMMERMANN ${ }^{1,2}$ \\ ${ }^{1}$ Department of Biochemistry and Molecular Biology, University of Massachusetts, Amherst, Massachusetts 01003, USA \\ ${ }^{2}$ Program in Molecular and Cellular Biology, University of Massachusetts, Amherst, Massachusetts 01003, USA \\ ${ }^{3}$ Department of Chemistry, University of Massachusetts, Amherst, Massachusetts 01003, USA
}

\begin{abstract}
Three new photoreactive tRNA derivatives have been synthesized for use as probes of the peptidyl transferase center of the ribosome. In two of these derivatives, the $3^{\prime}$ adenosine of yeast tRNA ${ }^{\text {Phe }}$ has been replaced by either 2 -azidodeoxyadenosine or 2-azido-2'-O-methyl adenosine, while in a third the 3 '-terminal 2-azidodeoxyadenosine of the tRNA is joined to puromycin via a phosphoramidate linkage to generate a photoreactive transition-state analog. All three derivatives bind to the $P$ site of $70 S$ ribosomes with affinities similar to that of unmodified $t R N A^{\text {Phe }}$ and can be cross-linked to components of the $50 S$ ribosomal subunit by irradiation with near-UV light. Characteristic differences in the cross-linking patterns suggest that these tRNA derivatives can be used to follow subtle changes in the position of the tRNA relative to the components of the peptidyl transferase center.
\end{abstract}

Keywords: peptidyl transferase center; photoreactive tRNA probes; ribosomes

\section{INTRODUCTION}

Dynamic interactions between the amino acid acceptor end of tRNA and the ribosome underlie the sequential synthesis of peptide bonds at the peptidyl transferase center of the $50 \mathrm{~S}$ ribosomal subunit (Schmeing et al. 2005b). Photocross-linking of the $3^{\prime}$-terminal residue of tRNA- which is adjacent to the attached amino acid or peptide-to components of the $50 \mathrm{~S}$ subunit has proven to be a sensitive means for identifying specific protein and RNA segments at the peptidyl transferase center. At the ribosomal $\mathrm{P}$ site, a derivative of yeast tRNA $^{\text {Phe }}$ with the photoreactive nucleoside 2 -azidoadenosine in position $76,\left(2 \mathrm{~N}_{3} \mathrm{~A} 76\right) \mathrm{tRNA}^{\mathrm{Phe}}$, crosslinks to nucleotides U2506 and U2585 of the 23S rRNA as well as to the N-terminal sequence of 50S-subunit protein L27 (Wower et al. 2000; Maguire et al. 2005), indicating their close proximity to the site of peptide bond formation. The role of these components in transpeptidation is also supported by numerous genetic, footprinting, modification-interference, and structural studies (Moazed and

Reprint requests to: Robert A. Zimmermann, Department of Biochemistry and Molecular Biology, University of Massachusetts, 710 North Pleasant Street, Amherst, MA 01003, USA; e-mail: zimmermann@ biochem.umass.edu; fax: (413) 545-3291.

Article published online ahead of print. Article and publication date are at http://www.rnajournal.org/cgi/doi/10.1261/rna.425907.
Noller 1989; Porse et al. 1996; Bocchetta et al. 1998; Maguire et al. 2005; Schmeing et al. 2005b). To further probe the peptidyl transferase center (PTC), we have developed three new photoreactive derivatives of yeast tRNA ${ }^{\text {Phe }}$ with modifications at position 76, one containing 2-azidodeoxyadenosine, $\left(2 \mathrm{~N}_{3} \mathrm{dA} 76\right) \mathrm{tRNA}^{\text {Phe }}$, a second containing 2-azido-2'-O-methyladenosine $\left(2 \mathrm{~N}_{3} 2^{\prime}\right.$ OMeA76)tRNA ${ }^{\text {Phe }}$, and a third, $\left(2 \mathrm{~N}_{3} \mathrm{dA76}\right) \mathrm{tRNA}^{\mathrm{Phe}}$-p-Puro, based on a transitionstate analog of peptidyl transferase designed by Yarus and coworkers (Welch et al. 1995).

The Yarus analog consists of a P-site moiety, CCdAp, joined to an A-site moiety, puromycin, via a phosphoramidate linkage between the $3^{\prime}$-phosphate of $\mathrm{dA}$ and the $\alpha$-amino group of puromycin (Welch et al. 1995). This analog, CCdApPuro, binds to Escherichia coli ribosomes with a $K_{d}$ in the submicromolar range and is a potent inhibitor of peptidyl transferase. Chemical footprinting experiments revealed that bound CCdApPuro affords protection to several nucleotides that are associated with the ribosomal $\mathrm{P}$ site. It is also a competitive inhibitor of the "fragment reaction" at the A site. This compound therefore appears to span the peptidyl transferase reaction center. Subsequent work has shown that the presence or absence of the 2'-OH group of the P-site A residue, equivalent to A76 in tRNA $^{\text {Phe }}$, does not significantly affect either the affinity of similar transition-state analogs for the $50 \mathrm{~S}$ subunit or 
their positioning at the PTC (Weinger et al. 2004; Schmeing et al. 2005a).

We have recently undertaken the synthesis of a photoreactive counterpart of CCdApPuro in which $\mathrm{dA}$ is replaced by 2-azidodeoxyadenosine $\left(2 \mathrm{~N}_{3} \mathrm{dA}\right)$ and the $\mathrm{CC}$ portion by an otherwise unmodified, full-length $\mathrm{tRNA}^{\text {Phe }}$ molecule. We anticipate that $\left(2 \mathrm{~N}_{3} \mathrm{dA} 76\right) \mathrm{tRNA}^{\mathrm{Phe}}$-p-Puro, like CCdApPuro, will bind simultaneously to the A and P sites and can therefore be used to monitor dynamic changes at the peptidyl transferase center that occur during peptide bond formation. There is in fact considerable evidence that peptide bond formation is accompanied by conformational rearrangements within the 23S rRNA (Polacek et al. 2000; Bayfield et al. 2001). In addition, significant differences in the position and orientation of nucleotides at the peptidyl transferase center have emerged from comparisons of $23 \mathrm{~S}$ rRNA conformation within the 50S subunits of Haloarcula marismortui, Deinococcus radiodurans, and Thermus thermophilus (Ban et al. 2000; Harms et al. 2001: Yusupov et al. 2001; Schmeing et al. 2005b). Cross-linking of $\left(2 \mathrm{~N}_{3} \mathrm{dA} 76\right)$ tRNA $^{\text {Phe }}$-p-Puro to the ribosome can be used to track changes in the orientation of the $3^{\prime}$ end of P-site tRNA relative to ribosomal components during peptide bond formation at the peptidyl transferase center, as labeling will occur from the position that corresponds to the $3^{\prime}$ A residue of P-site tRNA. Cross-linking patterns arising from the use of $\left(2 \mathrm{~N}_{3} \mathrm{dA76}\right) \mathrm{tRNA}{ }^{\text {Phe }}$-p-Puro can therefore be compared directly with those of P-site bound $\left(2 \mathrm{~N}_{3} \mathrm{~A} 76\right) \mathrm{tRNA}^{\mathrm{Phe}}$.

Here we show that the three new probes (1) bind efficiently to the $\mathrm{P}$ site of $E$. coli $70 \mathrm{~S}$ ribosomes with affinities similar to unmodified tRNA, (2) can be competed from the $\mathrm{P}$ site by unmodified tRNA, and (3) become crosslinked to protein and RNA components of the 50S subunit when irradiated with near-UV light. Characteristic differences in the cross-linking patterns suggest that these tRNA derivatives can be used to follow subtle changes in the position of the tRNA relative to the components of the peptidyl transferase center at different stages of peptide bond formation.

\section{RESULTS AND DISCUSSION}

The photoreactive nucleoside bisphosphates, $\mathrm{p} 2 \mathrm{~N}_{3} \mathrm{dAp}$ and p $2 \mathrm{~N}_{3} 2^{\prime} \mathrm{OMeAp}$, were synthesized and incorporated into the $3^{\prime}$-terminal position of yeast tRNA ${ }^{\text {Phe }}$ in place of A76 to yield the tRNA derivatives $\left(2 \mathrm{~N}_{3} \mathrm{dA} 76\right) \mathrm{tRNA}^{\text {Phe }}$ and $\left(2 \mathrm{~N}_{3} 2^{\prime} \mathrm{OMeA} 76\right) \mathrm{tRNA}^{\text {Phe }}$ (Fig. 1). In addition, we prepared a new, photoreactive transition-state analog, based on the Yarus analog, CCdApPuro (Welch et al. 1995), which consists of a P-site $\left(2 \mathrm{~N}_{3} \mathrm{dA} 76\right) \mathrm{tRNA}^{\text {Phe }}$ moiety joined to an A-site puromycin moiety by a $3^{\prime}$ phosphoramidate linkage. Together, the photoreactive tRNA derivatives and the photoreactive transition-state analog were used to probe the PTC, and their cross-linking patterns were compared.

\section{Synthesis of tRNA derivatives}

p2 $\mathrm{N}_{3} \mathrm{Ap}, \mathrm{p} 2 \mathrm{~N}_{3} \mathrm{dAp}$, and $\mathrm{p} 2 \mathrm{~N}_{3} 2^{\prime} \mathrm{OMeAp}$ were labeled with ${ }^{32} \mathrm{P}$ prior to ligation to the tRNA via an exchange reaction catalyzed by $3^{\prime}$-phosphatase-free polynucleotide kinase (PNK). The labeling efficiency of $\mathrm{p}_{2} \mathrm{~N}_{3} 2^{\prime} \mathrm{OMeAp}$ was significantly lower than that of the other two nucleotides. The incorporation of ${ }^{32} \mathrm{P}$ into all three nucleoside bisphosphates decreased with increasing amounts of ATP, most likely due to pyrophosphate and phosphate impurities present in the ATP stock that inhibited PNK. The addition of PEG-8000 to the exchange reaction significantly improved the labeling (Harrison and Zimmerman 1986), as did both PPase and PNP. PPase is presumed to stimulate the reaction by hydrolyzing inhibitory pyrophosphate (Lillehaug and Kleppe 1977), while PNP was used to convert inorganic phosphate into the noninhibitory ribose-1-phosphate, in the presence of inosine (Nixon et al. 1998). The bisphosphates were next ligated to the $3^{\prime}$ end of yeast tRNA ${ }^{\text {Phe }}$ from which A76 had been removed. PPase was also used to improve the efficiency of this reaction by removing pyrophosphate byproducts (Sabatini and Hajduk 1995). In the preparation of $\left(2 \mathrm{~N}_{3} \mathrm{dA} 76\right) \mathrm{tRNA}{ }^{\text {Phe }}$ and $\left(2 \mathrm{~N}_{3} 2^{\prime} \mathrm{OMeA} 76\right) \mathrm{tRNA}{ }^{\text {Phe }}$, the 3 '-terminal phosphate was removed by CIAP.

In the synthesis of the transition-state analog, $3^{\prime}$-phosphorylated $\left(2 \mathrm{~N}_{3} \mathrm{dA} 76\right)$ tRNA was condensed with puromycin to form $\left(2 \mathrm{~N}_{3} \mathrm{dA}\right.$ 76)tRNA-p-Puro. To verify the presence of puromycin, the product was digested with RNase T1 and the resulting oligonucleotides were subjected to electrophoresis on a denaturing $25 \%$ polyacrylamide gel alongside a T1 digest of $\left(2 \mathrm{~N}_{3} \mathrm{dA} 76\right)$ tRNA-p. The shortest ${ }^{32} \mathrm{P}$-labeled digestion fragments derived from $\left(2 \mathrm{~N}_{3} \mathrm{dA} 76\right)$ tRNA-p-Puro and $\left(2 \mathrm{~N}_{3} \mathrm{dA} 76\right)$ tRNA-p correspond to CACCdA-p-Puro and CACCdA-p, respectively. Figure 2 shows that the presence of puromycin leads to a characteristic electrophoretic mobility shift equivalent to $\sim 6$ nucleotides (nt), confirming that puromycin is joined to the $3^{\prime}$ end of the tRNA. This mobility shift was eliminated upon treatment of CACCdAp-Puro with 1\% TFA for 30 min, consistent with hydrolysis of the acid-labile phosphoramidate bond that joins puromycin to tRNA (Benkovic and Sampson 1971; Welch et al. 1995).

Since $\left(2 \mathrm{~N}_{3} \mathrm{dA}\right.$ 76)tRNA-p-Puro has a full-length tRNA as its P-site moiety, it resembles the transition state of peptidyl transfer more closely than the shorter analogs reported previously (Welch et al. 1995; Weinger et al. 2004; Schmeing et al. 2005a). It had been proposed earlier that interactions between the tRNA and the ribosome at sites remote from the PTC make an important contribution to precise substrate alignment (Bashan et al. 2003; Agmon et al. 2004).

\section{Binding of tRNA derivatives to $70 S$ ribosomes}

The interaction of the photoreactive tRNA derivatives and the transition-state analog with $70 \mathrm{~S}$ tight-couple ribosomes 


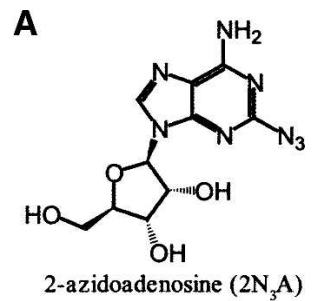

2-azidoadenosine $\left(2 \mathrm{~N}_{3} \mathrm{~A}\right)$

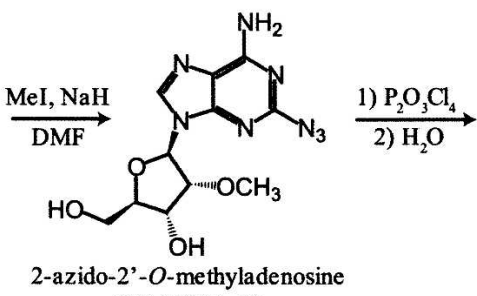

$\left(2 \mathrm{~N}_{3} 2\right.$ 'OMeA)

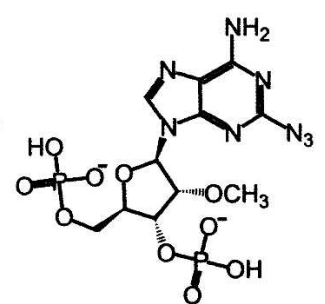

2-azido-2'-O-methyladenosine 3',5'-bisphosphate (p2 $\left.\mathrm{N}_{3} 2^{\prime} \mathrm{OMeAp}\right)$
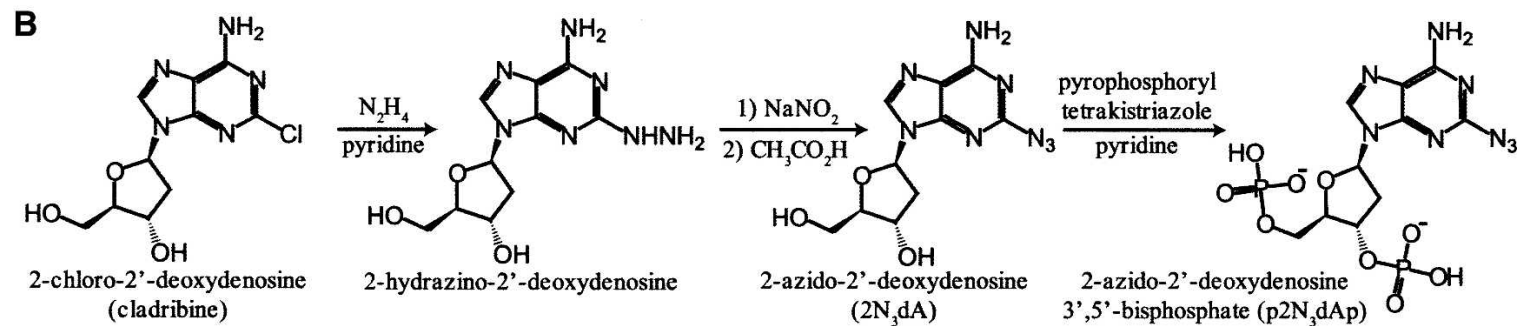

$\left(2 \mathrm{~N}_{3} \mathrm{dA}\right)$

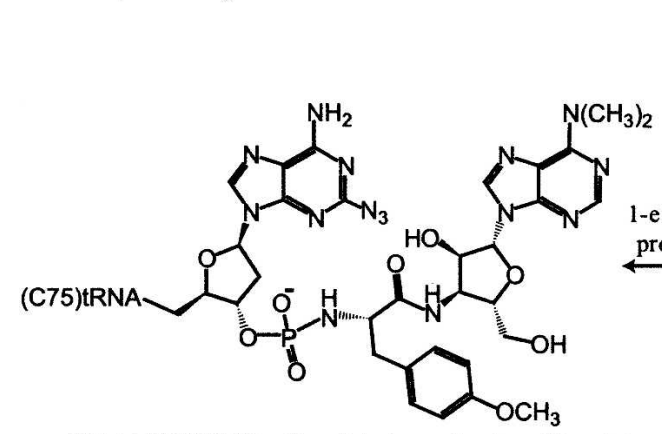

$\left(2 \mathrm{~N}_{3} \mathrm{dA} 76\right) \mathrm{tRNA}^{\mathrm{Phc}}$-p-Puro (photoreactive transition-state analog)

1-ethyl-3-[3-(dimethylamino)

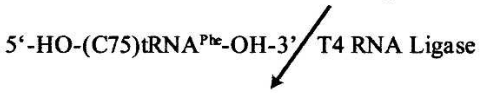

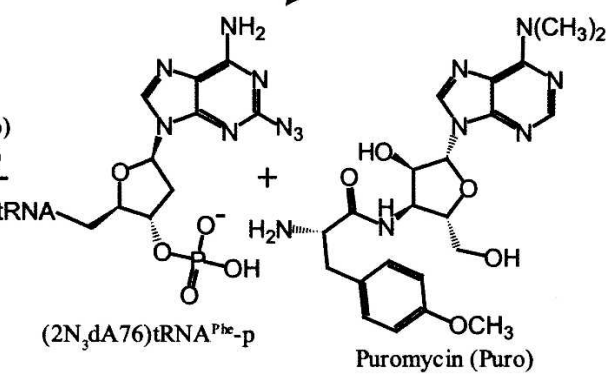

FIGURE 1. Synthetic schemes and structures of photoreactive nucleotides and modified tRNA ligands. (A) Synthesis of 2-azido-2'-Omethyladenosine $3^{\prime}, 5^{\prime}$-bisphosphate (p2 $\left.\mathrm{N}_{3} 2^{\prime} \mathrm{OMeAp}\right)$. (B) Synthesis of 2-azido-2'-deoxyadenosine $3^{\prime}, 5^{\prime}$-bisphosphate (p2 $\mathrm{N}_{3} \mathrm{dAp}$ ) and its final incorporation into the photoreactive transition-state analog $\left(2 \mathrm{~N}_{3} \mathrm{dA76}\right) \mathrm{tRNA}^{\text {Phe }}$-p-Puro.

was assessed by heterologous competition assays. ${ }^{32} \mathrm{P}$-labeled $\left(2 \mathrm{~N}_{3} \mathrm{~A} 76\right) \mathrm{tRNA},\left(2 \mathrm{~N}_{3} \mathrm{dA} 76\right) \mathrm{tRNA},\left(2 \mathrm{~N}_{3} 2^{\prime} \mathrm{OMeA76}\right) \mathrm{tRNA}$, and $\left(2 \mathrm{~N}_{3} \mathrm{dA} 76\right)$ tRNA-p-Puro were bound to $\operatorname{poly}(\mathrm{U})$ programmed ribosomes in P-site buffer in the presence of unlabeled yeast tRNA ${ }^{\text {Phe }}$ (Fig. 3). Homologous competition with unmodified tRNA ${ }^{\text {Phe }}$ was also performed. The amount of radiolabeled tRNA associated with the ribosomes at various competitor concentrations was measured by a nitrocellulose filter assay. In all cases, the unlabeled competitor, unmodified tRNA ${ }^{\text {Phe }}$, was able to fully displace the radioactive ligands, indicating competition for the same ribosomal binding site. Due to the very slow dissociation rate of tRNA from the $\mathrm{P}$ site at $4^{\circ} \mathrm{C}$ (half-life $\geq 10 \mathrm{~h}$; Lill et al. 1986), the radiolabeled and competitor ligands were mixed together before adding ribosomes, and the incubation was continued for about five dissociation half-lives in order to reach equilibrium. Relative affinity values for the ligands $\left(\mathrm{IC}_{50}\right)$ were determined from the competition data. The results show that all of the ligands have similar affinities for the ribosome.

\section{Cross-linking of tRNA analogs to the peptidyl transferase center}

Noncovalent complexes between the photoreactive ligands and poly(U)-programmed ribosomes were irradiated with 300-nm UV light. The irradiated ribosomes were then dissociated into subunits and fractionated by sucrosegradient centrifugation. Only the 50S subunits of the irradiated samples contained covalently bound, radioactive ligands (Fig. 4).

Cross-linked material was extracted from the isolated $50 \mathrm{~S}$ subunits and analyzed by PAGE. As shown in Figure 5, ${ }^{32}$ P-labeled $\left(2 \mathrm{~N}_{3} \mathrm{~A} 76\right)$ tRNA and $\left(2 \mathrm{~N}_{3} \mathrm{dA} 76\right)$ tRNA crosslinked to $23 \mathrm{~S}$ rRNA and to $50 \mathrm{~S}$-subunit proteins in a ratio of about 50:50, while the corresponding ratio for $\left(2 \mathrm{~N}_{3} 2^{\prime} \mathrm{OMeA} 76\right)$ tRNA was $60: 40$ and that for $\left(2 \mathrm{~N}_{3}\right.$ dA76)tRNA-p-Puro was 70:30, suggesting different orientations of the $3^{\prime}$ end of the P-site ligands relative to components of the PTC. Analysis of the cross-linked proteins by one- and two-dimensional PAGE revealed that ( $\left.2 \mathrm{~N}_{3} \mathrm{~A} 76\right) \mathrm{tRNA},\left(2 \mathrm{~N}_{3} \mathrm{dA} 76\right) \mathrm{tRNA}$, and $\left(2 \mathrm{~N}_{3} 2^{\prime} \mathrm{OMeA} 76\right) \mathrm{tRNA}$ 


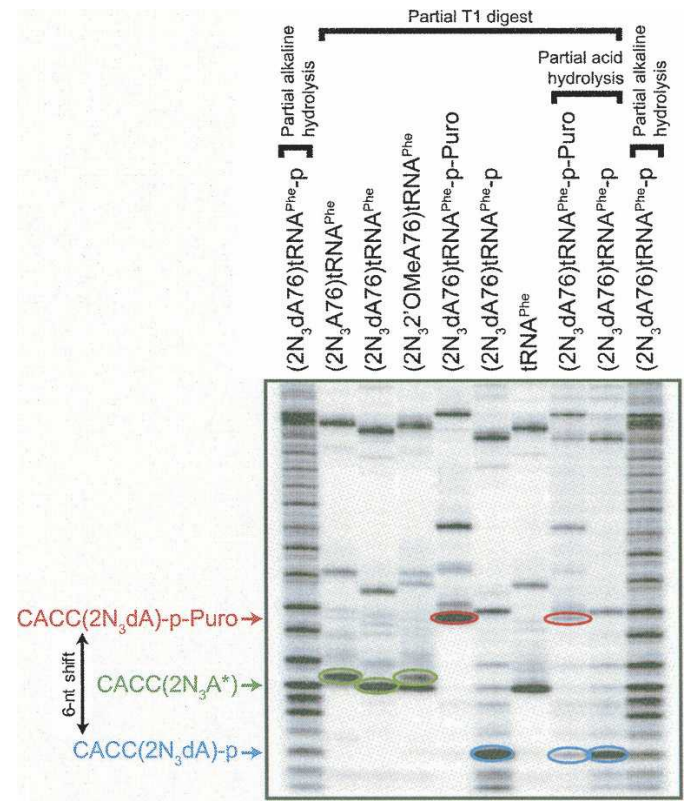

FIGURE 2. Analysis of modified photoreactive tRNA ligands. $\left(2 \mathrm{~N}_{3} \mathrm{~A} 76\right) \mathrm{tRNA}^{\text {Phe }}, \quad\left(2 \mathrm{~N}_{3} \mathrm{dA}\right.$ 76) tRNA ${ }^{\text {Phe }}, \quad\left(2 \mathrm{~N}_{3} 2^{\prime} \mathrm{OMeA} 76\right) \mathrm{tRNA}^{\text {Phe }}$, $\left(2 \mathrm{~N}_{3} \mathrm{dA}\right.$ 76) tRNA $^{\text {Phe }}$-p-Puro, $\left(2 \mathrm{~N}_{3} \mathrm{dA}\right.$-P6) tRNA $^{\text {Phe }}$-p, and unmodified tRNA $^{\text {Phe }}$, labeled with ${ }^{32} \mathrm{P}$ as described in Materials and Methods, were subjected to digestion with RNase T1 under partial conditions to avoid overdigestion. In addition, $\left.\left(2 \mathrm{~N}_{3} \mathrm{dA} 76\right)\right] \mathrm{tRNA}{ }^{\text {Phe }}$-p-Puro and $\left(2 \mathrm{~N}_{3} \mathrm{dA} 76\right)$ tRNA ${ }^{\text {Phe }}$-p were subjected to partial acid hydrolysis $(60 \mathrm{~min}$ in $1 \%$ trifluoroacetic acid at $23^{\circ} \mathrm{C}$ ) after $\mathrm{T} 1$ digestion. Partial alkaline digestion of $\left(2 \mathrm{~N}_{3} \mathrm{dA} 76\right)$ tRNA $^{\text {Phe }}$ - $\mathrm{p}$ was used to generate a reference ladder. The samples were resolved by denaturing 25\% PAGE and visualized by autoradiography. Labeled products released from the $3^{\prime}$ ends of the photoreactive tRNA ligands are $\operatorname{CACC}\left(2 \mathrm{~N}_{3} \mathrm{dA}\right)$, $\mathrm{CACC}\left(2 \mathrm{~N}_{3} 2^{\prime} \mathrm{OMeA}\right)$, and $\mathrm{CACC}\left(2 \mathrm{~N}_{3} \mathrm{~A}\right)$ (collectively designated as $\operatorname{CACC}\left[2 \mathrm{~N}_{3} \mathrm{~A}^{*}\right]$ in the figure), $\operatorname{CACC}\left(2 \mathrm{~N}_{3} \mathrm{dA}\right)$-p, and $\operatorname{CACC}\left(2 \mathrm{~N}_{3} \mathrm{dA}\right)-$ p-Puro. A characteristic mobility shift of about 6 nt in the $3^{\prime}$ T1 RNase product is observed when $\left(2 \mathrm{~N}_{3} \mathrm{dA} 76\right) \mathrm{tRNA}^{\mathrm{Phe}}-\mathrm{p}$ is condensed with puromycin. The observed 6-nt shift in $\left(2 \mathrm{~N}_{3} \mathrm{dA} 76\right) \mathrm{tRNA}^{\text {Phe }}$-p-Puro is reversed upon treatment with acid, consistent with hydrolysis of phosphoramidate linkage between $\left(2 \mathrm{~N}_{3} \mathrm{dA} 76\right) \mathrm{tRNA}^{\text {Phe }}$-p and puromycin (Benkovic and Sampson 1971; Welch et al. 1995).

labeled mainly L27, with a small amount of incorporation into L33 owing to the spillover of nonaminoacylated tRNA derivatives into the E-site (Fig. 6; see Maguire et al. 2005). In contrast, $\left(2 \mathrm{~N}_{3} \mathrm{dA76}\right)$ tRNA-p-Puro cross-linked exclusively to L27, since the transition-state analog spans the $\mathrm{P}$ and $\mathrm{A}$ sites and cannot spill into the E site.

The three new tRNA-derived ligands described in this report-all with photoreactive nucleotides at their $3^{\prime}$ termini-should prove useful in characterizing the interaction of tRNA with the PTC. They have been shown to bind to $70 \mathrm{~S}$ tight-couple ribosomes with affinities similar to that of unmodified tRNA and all can be cross-linked to RNA and protein components of the 50S ribosomal subunit upon irradiation with UV light. Furthermore, we find that the nature and extent of the protein cross-linking by the photoreactive transition-state analog differs from that
A

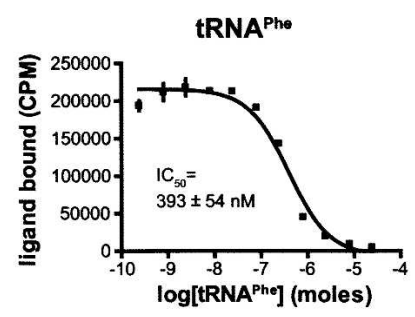

B

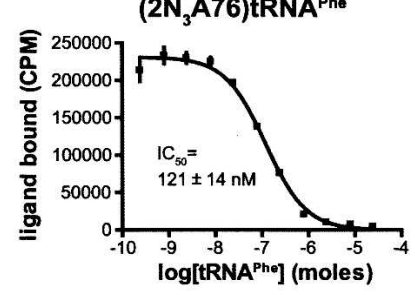

C

(2N ${ }_{3}$ dA76)tRNA ${ }^{\text {Phe }}$

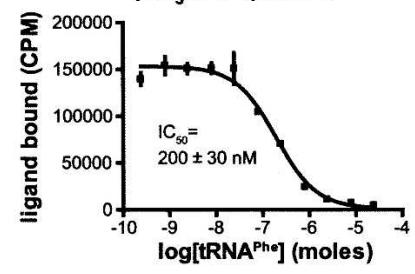

D

(2N ${ }_{3}{ }^{\prime}$ OMeA76)tRNA $A^{\text {Pho }}$

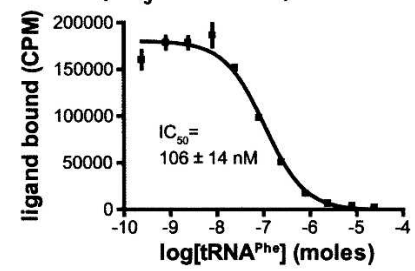

E

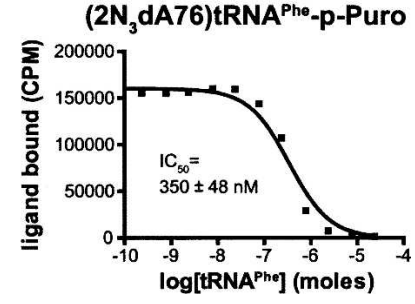

FIGURE 3. Competition binding assays. Radiolabeled $(A)$ unmodified tRNA ${ }^{\text {Phe }},(B)\left(2 \mathrm{~N}_{3} \mathrm{~A} 76\right) \mathrm{tRNA}^{\text {Phe }},(C)\left(2 \mathrm{~N}_{3} 2^{\prime} \mathrm{OMeA} 76\right) \mathrm{tRNA}^{\text {Phe }}$, (D) $\left(2 \mathrm{~N}_{3} \mathrm{dA} 76\right) \mathrm{tRNA}^{\text {Phe }}$, and $(E)\left(2 \mathrm{~N}_{3} \mathrm{dA} 76\right) \mathrm{tRNA}^{\text {Phe }}$-p-Puro $(\sim 100 \mathrm{nM})$ were first mixed with various concentrations of unlabeled, unmodified tRNA $^{\text {Phe }}$ and then mixed with 70 S ribosomes $(10 \mathrm{nM})$ in the presence of polyU and $20 \mathrm{mM} \mathrm{MgCl}$. The binding reactions were incubated at $4^{\circ} \mathrm{C}$ for $48 \mathrm{~h}$ to reach equilibrium and then analyzed by the nitrocellulose filter binding assay. Error bars represent the standard deviation of triplicate samples of each reaction. The concentrations of competing unlabeled, unmodified tRNA ${ }^{\text {Phe }}$ that displace $50 \%$ of the specifically bound radiolabeled ligand $\left(\mathrm{IC}_{50}\right)$ were calculated using the nonlinear regression function of GraphPad Prism software. In these assays, radiolabeled ligands with higher affinities for the ribosome lead to higher $\mathrm{IC}_{50}$ values. 
A

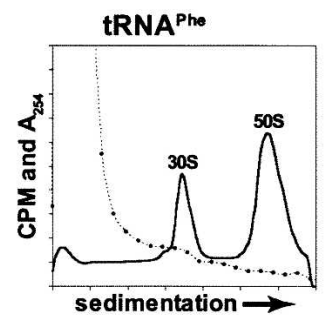

B

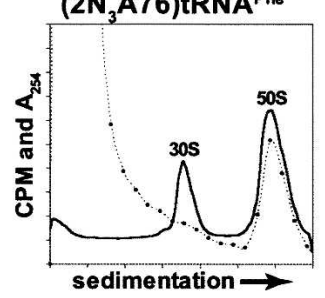

C

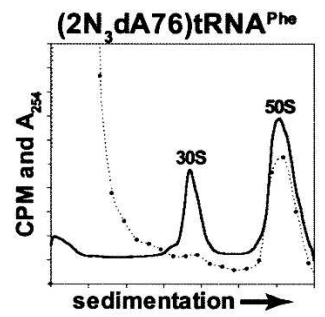

D $\quad\left(2 \mathrm{~N}_{3} 2^{\prime} \mathrm{OMeA76}\right)$ tRNA ${ }^{\text {Phe }}$

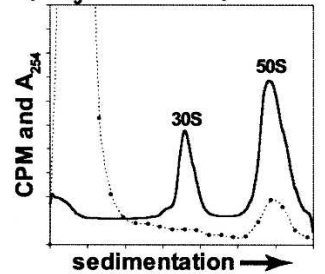

E

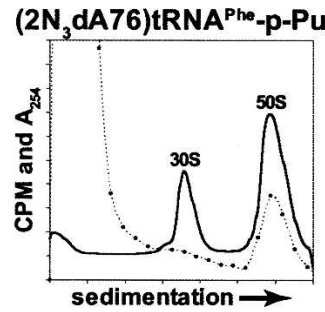

FIGURE 4. Sucrose-gradient profiles of dissociated ribosomal subunits after cross-linking. (A) unmodified tRNA ${ }^{\text {Phe }},(B)\left(2 \mathrm{~N}_{3} \mathrm{~A} 76\right)$ tRNA $^{\text {Phe }},(C)\left(2 \mathrm{~N}_{3} \mathrm{dA}\right.$ 76) tRNA ${ }^{\text {Phe }},(D)\left(2 \mathrm{~N}_{3} 2^{\prime} \mathrm{OMeA} 76\right) \mathrm{tRNA}^{\text {Phe }}$, and (E) $\left.\left(2 \mathrm{~N}_{3} \mathrm{dA} 76\right)\right]$ tRNA $^{\text {Phe }}$-p-Puro. Both UV absorbance (solid line) and radioactivity (dashed line with data points) were monitored as the gradients were fractionated. With the exception of unmodified tRNA ${ }^{\text {Phe }}$, the ligands cross-linked exclusively to the $50 \mathrm{~S}$ subunit, as shown by the comigration of radioactivity with the $50 \mathrm{~S}$ peak.

of the tRNA analogs. Identification of the cross-linked nucleotide(s) within the 23S rRNA, currently underway, should elucidate the extent to which the position of A76 in the P-site tRNA changes relative to the rRNA in the transition state.

\section{MATERIALS AND METHODS}

\section{Materials}

Yeast tRNA ${ }^{\text {Phe }}$, poly $(\mathrm{U})$, puromycin, yeast pyrophosphatase (PPase), yeast purine nucleoside phosphorylase (PNP), inosine, ADP, linear polyacrylamide (GeneElute), bovine serum albumin (BSA), and polyethylene glycol (PEG-8000) were from Sigma. T4 RNA ligase was from Epicentre Technologies; calf intestinal alkaline phosphatase (CIAP) and 3' phosphatase-free T4 polynucleotide kinase (PNK) were from Roche. 1-ethyl-3-[3-(dimethylamino)propyl]carbodiimide (EDC) was from Avocado Organics. 2-chloro-2'-deoxyadenosine (cladribine) was a product of General Intermediates of Canada. Partially purified $\left[\gamma^{-32} \mathrm{P}\right]$ ATP $(6000 \mathrm{Ci} / \mathrm{mmol})$ was obtained from Perkin Elmer Life Sciences. Forty percent polyacrylamide mix (acrylamide/bis-acrylamide, 19:1) was from Amresco, 96-well filter plates (MultiScreen-HA) were from Millipore, Nucleobond AX20 columns were from Machery \& Nagel, DEAE-Sephadex A-25 was from GE Healthcare, and precast $4 \%-20 \%$ polyacrylamide gradient gels were from Gradipore. MRE600 cells were from the University of Alabama

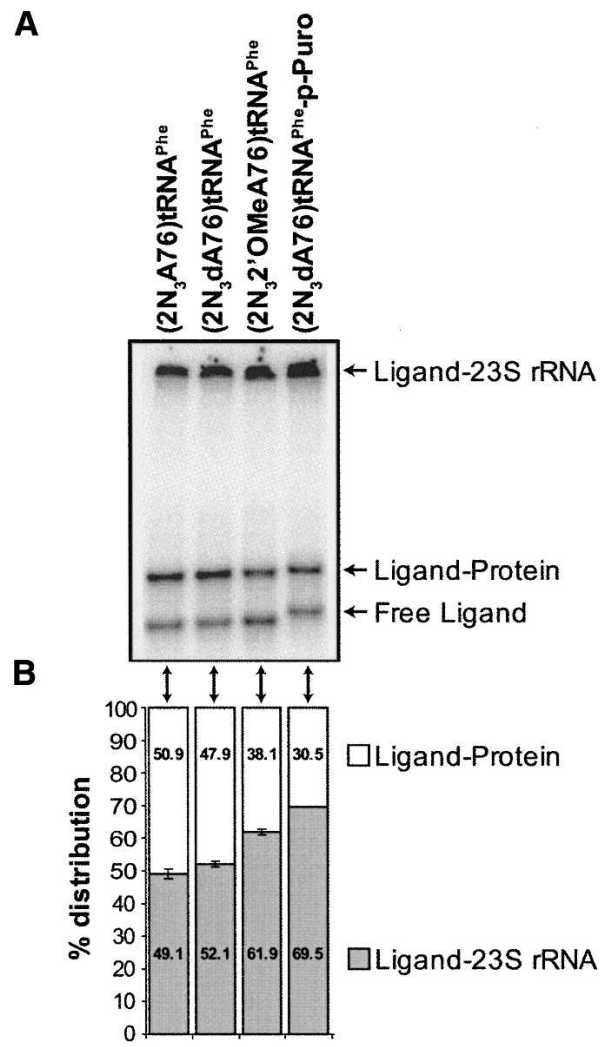

FIGURE 5. Analysis of the distribution of cross-links between $23 \mathrm{~S}$ rRNA and $50 \mathrm{~S}$-subunit proteins. $(A){ }^{32} \mathrm{P}$-labeled material isolated from $50 \mathrm{~S}$ subunits was resuspended in $6 \mathrm{M}$ urea, resolved by $4 \%-20 \%$ gradient SDS-PAGE, and visualized by autoradiography. With the exception of unmodified tRNA ${ }^{\text {Phe }}$, the ligands cross-linked to both $23 \mathrm{~S}$ rRNA and to proteins. (B) Bar graph showing the relative distribution of cross-linked 23S rRNA and protein estimated by PhosphorImager analysis of the gels. Error bars represent the standard deviation in measurements obtained from three separate SDS-PAGE runs. 
A

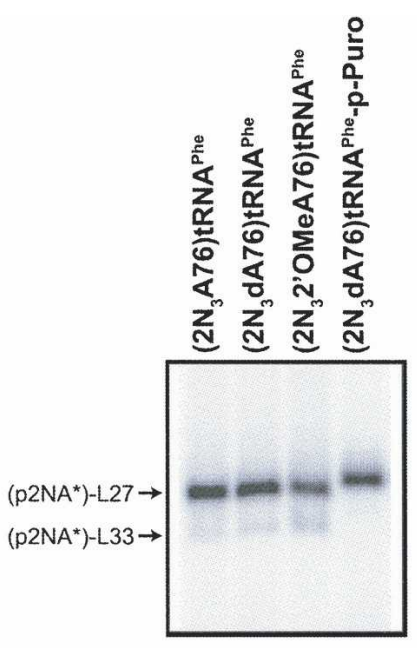

B
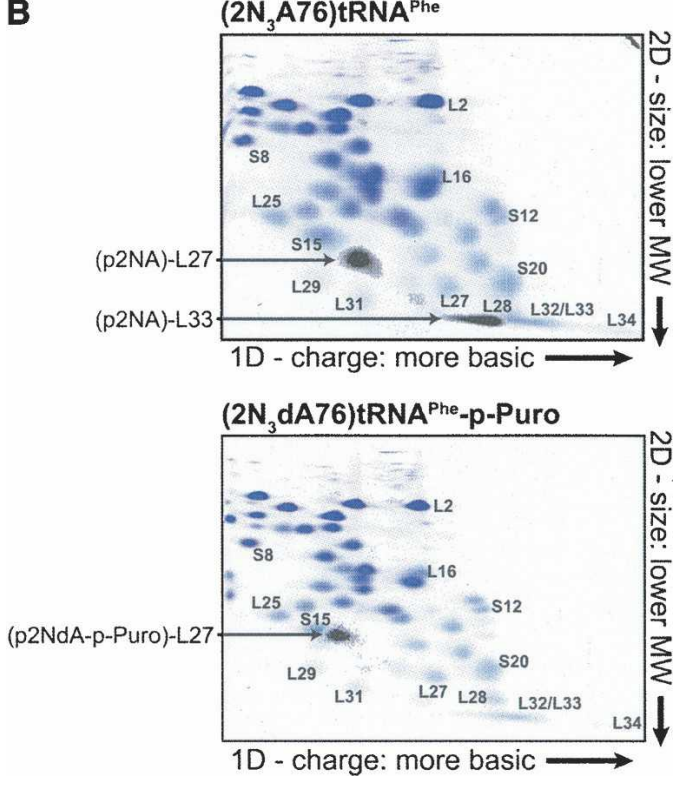

FIGURE 6. Identification of ribosomal proteins cross-linked by each photoreactive ligand. 50S-subunit components were solubilized in $6 \mathrm{M}$ urea and incubated with ribonuclease S1, which entirely digested the RNA, leaving a radioactively labeled $5^{\prime}$-phosphate and its modified A76 nucleotide covalently attached to a ribosomal protein. The digested material was resolved by $(A)$ 10\% SDS-PAGE and by $(B)$ two-dimensional PAGE, and then visualized by autoradiography. In panel $A$ the labeled bands contain different derivatives of $A 76$, collectively designated as $A^{\star}$. In panel $B$, the samples were spiked with nonradioactive proteins that were acid-extracted from purified $70 \mathrm{~S}$ ribosomes to provide reference markers. The proteins in the two-dimensional (2D) gel were stained with bromophenol blue and the image was overlaid with the autoradiogram of the same gel. The positions of (p2NA)-L27, (p2NA)-L33, and (2NdA-pPuro)-L27 are displaced from those of L27 and L33 owing to the presence of the negatively charged nucleotide moieties (Maguire et al. 2005).

Fermentation Facility. Plasmid pQECCA, which encodes Histagged yeast nucleotidyl transferase under lac regulation, was the generous gift of Dr. D.L. Thurlow, Clark University, Worcester, MA.

\section{Preparation of $70 S$ tight-couple ribosomes}

For the isolation of tight-couple $70 \mathrm{~S}$ ribosomes, $\sim 10 \mathrm{~g}$ of MRE600 cells were broken by grinding with alumina and further processed as described (Rheinberger et al. 1988; Maguire et al. 2005).

\section{Synthesis of photoreactive nucleotides}

\author{
2-Azidoadenosine-3', $5^{\prime}$-bisphosphate (p2 $\left.\mathrm{N}_{3} A p\right)$
}

p2 $\mathrm{N}_{3}$ Ap was prepared according to Sylvers et al. (1989).

\section{2-Azido-2'-deoxyadenosine-3', $5^{\prime}$-bisphosphate ( $\left.p 2 \mathrm{~N}_{3} d A p\right)$}

2-Azido-2'-deoxyadenosine was synthesized from 2-chloro-2'deoxyadenosine (cladribine) as described (Lioux et al. 2003). Fifty-four milligrams $(0.18 \mathrm{mmol})$ of 2 -azido-2'-deoxyadenosine, $83 \mathrm{mg}(1.2 \mathrm{mmol})$ of 1,2,4-triazole, $42 \mu \mathrm{L}(0.3 \mathrm{mmol})$ of pyrophosphoryl chloride, and $121 \mathrm{mg}(1.2 \mathrm{mmol})$ of triethylamine were reacted in $6 \mathrm{~mL}$ of pyridine following the procedure of Folkman et al. (1990). The crude product obtained by quenching the reaction with ice-cold $1 \mathrm{M}$ triethylammonium bicarbonate solution $(\mathrm{pH} 7)$ was chromatographed on a $2 \times 40-\mathrm{cm}$ DEAE Sephadex A-25 column using a 1200-mL linear gradient of $0.05-$ $2 \mathrm{M}$ triethylammonium buffer ( $\mathrm{pH} 7.5$ ) to give 2-azido-2'-deoxyadenosine- $3^{\prime}, 5^{\prime}$-bisphosphate in $5 \%$ yield. The compound was identified by its mass spectrum (electrospray, negative ion mode, $\mathrm{m} / \mathrm{z} 451.2[\mathrm{M}-1])$ and by changes in its ultraviolet spectrum as a function of $\mathrm{pH}$, which were similar to those reported for 2-azidoadenosine (MacFarlane et al. 1982).

\section{2-Azido-2' -O-methyladenosine-3', 5' -bisphosphate $\left(p 2 \mathrm{~N}_{3} 2^{\prime} \mathrm{OMeAp}\right)$}

The method used to prepare 2-azido-2'-O-methyladenosine was very similar to that for $2^{\prime}$-O-methyladenosine (Yano et al. 1980) except that a greater than fourfold molar excess of sodium hydride was used since equimolar amounts of base and nucleoside appeared to give mostly the N-6-methylated compound. One hundred twenty milligrams $(0.388 \mathrm{mmol})$ of vacuum-dried 2-azidoadenosine were dissolved in $9 \mathrm{~mL}$ of anhydrous DMF and cooled to $-20^{\circ} \mathrm{C}$, after which $40.8 \mathrm{mg}(1.70 \mathrm{mmol})$ of sodium hydride were added. Next, a solution containing $62 \mu \mathrm{L}(0.463 \mathrm{mmol})$ of methyl iodide in $0.5 \mathrm{~mL}$ of anhydrous DMF was added dropwise over a 1 - $\mathrm{h}$ period. The mixture was stirred for $2 \mathrm{~h}$ at $25^{\circ} \mathrm{C}$ and then quenched by the addition of $131.2 \mathrm{mg}(1.702 \mathrm{mmol})$ of ammonium acetate. The crude product was purified by flash column chromatography to give 2-azido-2'-O-methyladenosine in $25 \%$ yield. The compound was identified by its mass spectrum (electrospray, positive ion mode, $\mathrm{m} / \mathrm{z} 323.5[\mathrm{M}+1]$ ) and by ${ }^{1} \mathrm{H}$ NMR. The compound was then phosphorylated and purified exactly as 2-azidoadenosine- $3^{\prime}, 5^{\prime}$-bisphosphate (Sylvers et al. 1989) to give 2-azido-2'-O-methyladenosine- $3^{\prime}, 5^{\prime}$-bisphosphate in $50 \%$ yield. The compound was identified by its mass spectrum (electrospray, negative ion mode, $\mathrm{m} / \mathrm{z} 481.5[\mathrm{M}-1]$ ) and by its ${ }^{31} \mathrm{P}$ NMR spectrum $\left(\mathrm{D}_{2} \mathrm{O}, \mathrm{pH} 10 ; 85 \% \mathrm{H}_{3} \mathrm{PO}_{4}\right.$ external standard), which showed signals for the $3^{\prime}$-phosphates of the azide and tetrazole tautomers at $\delta 4.34$ and 4.35 and for the $5^{\prime}$-phosphates at $\delta 3.90$ and 3.95 (Barrio et al. 1978). 


\section{Labeling of photoreactive nucleotides with ${ }^{32} \mathbf{P}$}

Nucleoside- $3^{\prime}, 5^{\prime}$-bisphosphates were labeled with ${ }^{32} \mathrm{P}$ at the $5^{\prime}$ position using a phosphate exchange reaction essentially as described by Sylvers et al. (1989). In brief, the nucleotide- $3^{\prime}, 5^{\prime}$ bisphosphate $(0.25 \mathrm{mM})$ was incubated for $30 \mathrm{~min}$ at $37^{\circ} \mathrm{C}$ in a buffer containing $50 \mathrm{mM}$ imidazole ( $\mathrm{pH}$ 6.6), $0.25 \mathrm{mM}$ ADP, $10 \mathrm{mM} \mathrm{MgCl}_{2}, 0.1 \mathrm{mM}$ EDTA, $10 \mathrm{mM}$ inosine, $12.5 \mu \mathrm{M}\left[\gamma_{-}{ }^{32} \mathrm{P}\right] \mathrm{ATP}$ $(6000 \mathrm{Ci} / \mathrm{mmol})$, and PEG-8000 $(5 \% \mathrm{w} / \mathrm{v})$ in the presence of yeast PPase $(25 \mathrm{U} / \mathrm{mL})$ and yeast PNP $(25 \mathrm{U} / \mathrm{mL})$. T4 polynucleotide kinase, $3^{\prime}$-phosphatase free $(500 \mathrm{U} / \mathrm{mL})$, was then added and the reaction continued for another $30 \mathrm{~min}$, after which it was quenched by heating for $1 \mathrm{~min}$ at $95^{\circ} \mathrm{C}$. The ${ }^{32} \mathrm{P}$-labeled nucleoside bisphosphates were ligated to tRNA without further purification (Barrio et al. 1978; England and Uhlenbeck 1978).

\section{Preparation of $\mathrm{tRNA}$}

Yeast nucleotidyl transferase was expressed from plasmid pQECCA in E. coli JM109 and purified as described (Maguire et al. 2005). The $3^{\prime}$ terminus of yeast $\mathrm{tRNA}^{\text {Phe }}$ was regenerated using purified yeast nucleotidyl transferase, and the regenerated tRNA was subjected to a single cycle of the Whitfeld degradation to remove the $3^{\prime}$-terminal A76 (Wower et al. 1988). ${ }^{32} \mathrm{P}$-labeled nucleoside-3',5'-bisphosphates were ligated to the $3^{\prime}$ end of tRNA lacking A76 (Sylvers et al. 1989). Ligation mixtures, which consisted of $2 \mu \mathrm{M}$ tRNA (or $1 \mu \mathrm{M}$ of tRNA for the ligation of p2 $\mathrm{N}_{3} \mathrm{Ap}$ ) and $4 \mu \mathrm{M}$ nucleoside- $3^{\prime}, 5^{\prime}$-bisphosphate in $50 \mathrm{mM}$ HEPES (pH 7.5), $15 \mathrm{mM} \mathrm{MgCl}_{2}, 10 \mu \mathrm{M}$ ATP, 15\% (v/v) DMSO, and $10 \mu \mathrm{g} / \mathrm{mL} \mathrm{BSA}$, and contained 10 units/mL of yeast PPase and 320 units $/ \mathrm{mL}$ of T4 RNA ligase, were incubated at $4^{\circ} \mathrm{C}$ for $19 \mathrm{~h}$. The resulting ${ }^{32} \mathrm{P}$-labeled tRNA-p was diluted twofold with $0.1 \mathrm{M}$ Tris acetate $(\mathrm{pH} 6.3)$ and $15 \%$ ethanol, and then applied to a Nucleobond AX20 column. The column was washed with $4 \mathrm{~mL}$ of $0.1 \mathrm{M}$ Tris acetate $(\mathrm{pH} 6.3), 0.2 \mathrm{M} \mathrm{NaCl}$, and $15 \%$ ethanol to remove unincorporated nucleotides and enzymes used in the previous steps, followed by $4 \mathrm{~mL}$ of $30 \%$ ethanol. The tRNA-p sample was eluted with $1.0 \mathrm{~mL}$ of $0.6 \mathrm{M} \mathrm{NaOAc}$ and $30 \%$ ethanol and precipitated by adding ethanol to $70 \%$ and decreasing the $\mathrm{pH}$ to about 5.2 with glacial acetic acid. Linear polyacrylamide (GeneElute) was used as a coprecipitant. When necessary, the tRNA-p was treated with CIAP to remove the $3^{\prime}$ phosphate. The resulting tRNAs were further purified by denaturing polyacrylamide gel electrophoresis (PAGE) and extracted as described (Maguire et al. 2005).

\section{Preparation of $\left(2 \mathrm{~N}_{3} \mathrm{dA76}\right) \mathrm{tRNA}-\mathrm{p}-$ Puro}

$\left(2 \mathrm{~N}_{3} \mathrm{dA76}\right)$ tRNA-p was condensed with puromycin by a method similar to that reported by Welch et al. (1995). The reaction was carried out overnight at room temperature in a $50 \mu \mathrm{L}$ reaction mixture containing $100-150 \mathrm{nmol}$ of $\left(2 \mathrm{~N}_{3} \mathrm{dA76}\right) \mathrm{tRNA}-\mathrm{p}, 75 \mathrm{mM}$ neutralized puromycin, 0.4 M EDC, and 0.4 M MES ( $\mathrm{pH} 5.6$ ). The reactants were then diluted by addition of $250 \mu \mathrm{L}$ of RNA extraction buffer $\left(0.5 \mathrm{M} \mathrm{NH}_{3}{ }^{+}\right.$acetate, $10 \mathrm{mM} \mathrm{Mg}^{++}$acetate, $1 \mathrm{mM}$ EDTA, 1\% SDS), extracted with phenol and chloroform, and precipitated. The sample was then resuspended in $15 \mu \mathrm{L}$ of RNA loading dye $(90 \mathrm{mM}$ Tris- $90 \mathrm{mM}$ boric acid at $\mathrm{pH} 8.3$, $2 \mathrm{mM}$ EDTA, $6 \mathrm{M}$ urea, $0.03 \%$ xylene cyanol, $0.03 \%$ bromophenol blue), resolved by $43-\mathrm{cm}$ denaturing $8 \%$ PAGE, and extracted (Maguire et al. 2005). Typical reaction yields were over $80 \%$. The purity and homogeneity of the resulting $\left(2 \mathrm{~N}_{3} \mathrm{dA76}\right)$ tRNA-p-Puro were routinely checked by RNase T1 digestion, followed by analysis of the digested fragments by $25 \%$ denaturing PAGE.

\section{Competitive binding of tRNA ligands to ribosomes}

Heterologous competition binding of tRNA ligands to the P site of the $70 \mathrm{~S}$ tight-couple ribosomes was performed in $15 \mu \mathrm{L}$ reaction mixtures under conditions similar to those of Wower et al. (1988). P-site buffer consisted of $50 \mathrm{mM}$ Tris- $\mathrm{HCl}$ ( $\mathrm{pH} 7.5$ ), $100 \mathrm{mM}$ $\mathrm{NH}_{3} \mathrm{Cl}$, and $20 \mathrm{mM} \mathrm{MgCl}$. Various concentrations of unlabeled competitor yeast tRNA ${ }^{\text {Phe }}$, whose $3^{\prime}$ terminus had been regenerated by yeast nucleotidyl transferase, were used. The unlabeled and radiolabeled ligands were mixed and, after the addition of ribosomes, the mixtures were incubated for $48 \mathrm{~h}$ at $4^{\circ} \mathrm{C}$ to reach equilibrium. Following incubation, $180 \mu \mathrm{L}$ of binding buffer were added to each mixture. The mixtures were immediately filtered and washed twice with $200 \mu \mathrm{L}$ of the same buffer using a 96-well nitrocellulose filter plate. As the hydrophobicity of $\left(2 \mathrm{~N}_{3} \mathrm{dA76}\right)$ tRNA-p-Puro results in an unusually high background in this assay, 5\% DMSO was added to the buffer with which the filters were washed after ligand deposition. The addition of DMSO dramatically reduces nonspecific binding of the ligand to the filter but has no significant effect on the binding of the ligand to ribosomes (data not shown). The filter plates were next disassembled and exposed to an imaging screen that was scanned using a Fuji FLA-5000 Imaging System; the radioactivity was quantified with the aid of Fuji Multi Gage software. Each competition binding reaction was performed in triplicate; relative affinity values $\left(\mathrm{IC}_{50}\right)$ were determined by fitting displacement binding inhibition values by nonlinear regression using Prism data software (GraphPad, Inc.).

\section{Cross-linking of tRNA to ribosomes and analysis of cross-links}

Cross-linking of tRNA ligands to $70 \mathrm{~S}$ tight-couple ribosomes was performed in 100-1000 $\mu \mathrm{L}$ reaction mixtures according to Wower et al. (1988). Sample mixtures were spotted onto a Petri dish that was placed on ice and irradiated for $5 \mathrm{~min}$ at $300 \mathrm{~nm}$ in a Rayonet RPR-100 photochemical reactor (Southern New England Ultra Violet Company) with six RPR-3000 lamps installed. The emitted light was filtered through a polystyrene Petri dish cover and a $0.025-\mathrm{mm}$ cellulose triacetate sheet to significantly reduce the transmission of light below $300 \mathrm{~nm}$. The sample was then precipitated with two volumes of ethanol and processed as described (Maguire et al. 2005). In brief, the 50S subunits were separated by centrifugation through $15 \%-30 \%$ (w/v) sucrose gradients and recovered using an ISCO density gradient fractionator. To estimate the proportion of tRNA that was covalently bound to $23 \mathrm{~S}$ ribosomal RNA or to ribosomal proteins, a portion of the cross-linked sample was subjected to SDS-PAGE using a $4 \%-20 \%(\mathrm{w} / \mathrm{v})$ gradient gel. The gel was dried and exposed to an imaging screen and radioactivity was quantified using a Fuji FLA5000 imager. Cross-linked tRNA-protein adducts were isolated and analyzed by one- and two-dimensional polyacrylamide gel electrophoresis as described (Maguire et al. 2005). 


\section{ACKNOWLEDGMENTS}

We are grateful to Dr. Charles Dickenson for assistance with the

${ }^{31} \mathrm{P}$ NMR measurements. This work was supported by grant GM 67267 From the National Institutes of Health.

Received December 5, 2006; accepted February 12, 2007.

\section{REFERENCES}

Agmon, I., Amit, I., Auerbach, T., Bashan, A., Baram, D., Bartels, H., Berisio, R., Greenberg, I., Harms, J., Hansen, H.A.S., et al. 2004. Ribosomal crystallography: A flexible nucleotide anchoring tRNA translocation, facilitates peptide-bond formation, chirality discrimination, and antibiotics synergism. FEBS Lett. 567: 20-26.

Ban, N., Nissen, P., Hansen, J., Moore, P.B., and Steitz, T.A. 2000. The complete atomic structure of the large ribosomal subunit at $2.4 \AA$ resolution. Science 289: 905-920.

Barrio, J.R., Barrio, M.C., Leonard, N.J., England, T.E., and Uhlenbeck, O.C. 1978. Synthesis of modified nucleoside $3^{\prime}, 5^{\prime}$ bisphosphates and their incorporation into oligoribonucleotides with T4 RNA ligase. Biochemistry 17: 2077-2081.

Bashan, A., Agmon, I., Zarivach, R., Schluenzen, F., Harms, J., Berisio, R., Bartels, H., Franceschi, F., Auerbach, T., Hansen, H.A.S., et al. 2003. Structural basis of the ribosomal machinery for peptide bond formation, translocation, and nascent chain progression. Mol. Cell 11: 91-102.

Bayfield, M.A., Dahlberg, A.E., Schulmeister, U., Dorner, S., and Barta, A. 2001. A conformational change in the ribosomal peptidyl transferase center upon active/inactive transition. Proc. Natl. Acad. Sci. USA 98: 10096-10101.

Benkovic, S.J. and Sampson, E.J. 1971. Structure-reactivity correlation for the hydrolysis of phosphoramidate monoanions. J. Am. Chem. Soc. 93: 4009-4016.

Bocchetta, M., Xiong, L., and Mankin, A.S. 1998. 23 rRNA positions essential for tRNA binding in ribosomal functional sites. Proc. Natl. Acad. Sci. 95: 3525-3530.

England, T.E. and Uhlenbeck, O.C. 1978. Enzymatic oligoribonucleotide synthesis with T4 RNA ligase. Biochemistry 17: 2069-2076.

Folkman, W., Kusmierek, J.T., and Singer, B. 1990. A new one-step method for the preparation of $3^{\prime}, 5^{\prime}$-bisphosphates of acid-labile deoxynucleosides. Chem. Res. Toxicol. 3: 536-539.

Harms, J., Schluenzen, F., Zarivach, R., Bashan, A., Gat, S., Agmon, I., Bartels, H., Franceschi, F., and Yonath, Y. 2001. High-resolution structure of the large ribosomal subunit from a mesophilic eubacterium. Cell 107: 679-688.

Harrison, B. and Zimmerman, S.B. 1986. Stabilization of T4 polynucleotide kinase by macromolecular crowding. Nucleic Acids Res. 14: $1863-1870$

Lill, R., Robertson, J.M., and Wintermeyer, W. 1986. Affinities of tRNA binding sites of ribosomes from Escherichia coli. Biochemistry 25: 3245-3255.

Lillehaug, J.R. and Kleppe, K. 1977. Phosphorylation of tRNA by $\mathrm{T}_{4}$ polynucleotide kinase. Nucleic Acids Res. 4: 373-380.

Lioux, T., Gosselin, G., and Mathé, C. 2003. Azido/tetrazole tautomerism in 2-azidoadenine $\beta$-D-pentofuranonucleoside derivatives. Eur. J. Org. Chem. 2003: 3997-4002.

MacFarlane, D.E., Mills, D.C.B., and Srivastava, P.C. 1982. Binding of 2-azidoadenosine $\left[\alpha-{ }^{32} \mathrm{P}\right]$ diphosphate to the receptor on intact human blood platelets which inhibits adenylate cyclase. Biochemistry 21: $544-549$.

Maguire, B.A., Beniaminov, A.D., Ramu, H., Mankin, A.S., and Zimmermann, R.A. 2005. A protein component at the heart of an RNA machine: The importance of protein L27 for the function of the bacterial ribosome. Mol. Cell 20: 427-435.

Moazed, D. and Noller, H.F. 1989. Interaction of tRNA with $23 \mathrm{~S}$ rRNA in the ribosomal A, P, and E sites. Cell 57: 585-597.

Nixon, A.E., Hunter, J.L., Bonifacio, G., Eccleston, J.F., and Webb, M.R. 1998. Purine nucleoside phosphorylase: Its use in a spectroscopic assay for inorganic phosphate and for removing inorganic phosphate with the aid of phosphodeoxyribomutase. Anal. Biochem. 265: 299-307.

Polacek, N., Patzke, S., Nierhaus, K.H., and Barta, A. 2000. Periodic conformational changes in rRNA: Monitoring the dynamics of translating ribosomes. Mol. Cell 6: 159-171.

Porse, B.T., Thi-Ngoc, H.P., and Garrett, R.A. 1996. The donor substrate site within the peptidyl transferase loop of $23 \mathrm{~S}$ rRNA and its putative interactions with the CCA-end of N-blocked aminoacyl-tRNA tRNA ${ }^{\text {Phe }}$. J. Mol. Biol. 264: 472-483.

Rheinberger, H.J., Geigenmuller, U., Wedde, M., and Nierhaus, K.H. 1988. Parameters for the preparation of Escherichia coli ribosomes and ribosomal subunits active in tRNA binding. Methods Enzymol. 164: 658-670.

Sabatini, R. and Hajduk, S.L. 1995. RNA ligase and its involvement in guide RNA/mRNA chimera formation. J. Biol. Chem. 270: 7233-7240.

Schmeing, T.M., Huang, K.S., Kitchen, D.E., Strobel, S.A., and Steitz, T.A. 2005a. Structural insights into the roles of water and the 2'-hydoxyl of the P-site tRNA in the peptidyl transferase reaction. Mol. Cell 20: 437-438.

Schmeing, T.M., Huang, K.S., Strobel, S.A., and Steitz, T.A. 2005b. An induced-fit mechanism to promote peptide bond formation and exclude hydrolysis of peptidyl-tRNA. Nature 438: 520-524.

Sylvers, L.A., Wower, J., Hixson, S.S., and Zimmermann, R.A. 1989. Preparation of 2-azidoadenosine $3^{\prime}, 5^{\prime}-\left[5^{\prime}-{ }^{32} \mathrm{P}\right]$ bisphosphate for incorporation into transfer RNA. Photoaffinity labeling of Escherichia coli ribosomes. FEBS Lett. 245: 9-13.

Weinger, J.S., Kitchen, D., Scaringe, S.A., Strobel, S.A., and Muth, G.W. 2004. Solid phase synthesis and binding affinity of peptidyl transferase transition state mimics containing $2^{\prime}-\mathrm{OH}$ at P-site position A76. Nucleic Acids Res. 32: 1502-1511.

Welch, M., Chastang, J., and Yarus, M. 1995. An inhibitor of ribosomal peptidyl transferase using transition-state analogy. Biochemistry 34: 387-390.

Wower, J., Hixson, S.S., and Zimmermann, R.A. 1988. Photochemical cross-linking of yeast tRNA $^{\text {Phe }}$ containing 8 -azidoadenosine at positions 73 and 76 to the Escherichia coli ribosome. Biochemistry 27: 8114-8121.

Wower, J., Kirillov, S.V., Wower, I.K., Guven, S., Hixson, S.S., and Zimmermann, R.A. 2000. Transit of tRNA through the Escherichia coli ribosome. Cross-linking of the $3^{\prime}$ end of tRNA to specific nucleotides of the $23 \mathrm{~S}$ ribosomal RNA at the A, P, and E sites. J. Biol. Chem. 275: 37887-37894.

Yano, J., Kan, L.S., and Ts'o, P.O. 1980. A simple method of the preparation of $2^{\prime}$-O-methyladenosine. Methylation of adenosine with methyl iodide in anhydrous alkaline medium. Biochim. Biophys. Acta 629: 178-183.

Yusupov, M.M., Yusupova, G.Zh., Baucom, A., Lieberman, K., Earnest, T.N., Cate, J.H.D., and Noller, H.F. 2001. Crystal structure of the ribosome at 5.5 A resolution. Science 292: 883-896. 

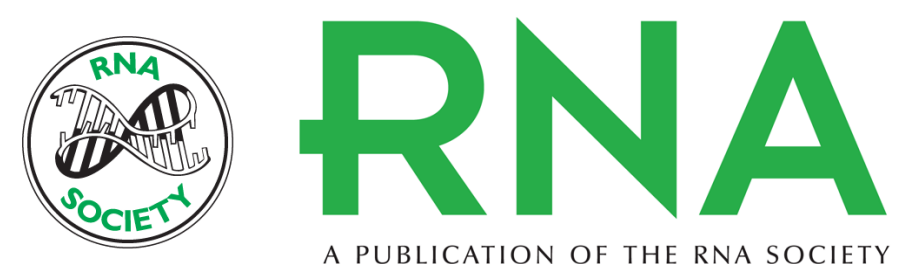

A PUBLICATION OF THE RNA SOCIETY

\section{New photoreactive tRNA derivatives for probing the peptidyl transferase center of the ribosome}

Anton V. Manuilov, Stephen S. Hixson and Robert A. Zimmermann

RNA 2007 13: 793-800 originally published online March 22, 2007

Access the most recent version at doi:10.1261/rna.425907

$\begin{array}{ll}\text { References } & \begin{array}{l}\text { This article cites } 31 \text { articles, } 6 \text { of which can be accessed free at: } \\ \text { http://rnajournal.cshlp.org/content/13/5/793.full.html\#ref-list-1 }\end{array}\end{array}$

License

Email Alerting Receive free email alerts when new articles cite this article - sign up in the box at the Service top right corner of the article or click here. 